\title{
Çocuklarda fonksiyonel kabızlık tedavisinin yaşam kalitesi üzerine etkisi
}

\author{
Impact of treatment on quality of life in children with functional constipation
}

Hüseyin KILINÇASLAN, Osman ABALI, İbrahim AYDOĞDU, Mustafa BİLİCİ

\section{ÖZET}

Amaç: Bu çalışmanın amacı okul öncesi dönemde fonksiyonel kabızlığı (FK) olan çocuklarda standart tedavi sonrasında yaşam kalitelerinde değişiklik olup olmadığının değerlendirilmesidir.

Hastalar ve Yöntem: İki ve altı yaşlar arasındaki FK tanılı altmış beş hasta çalışmaya dahil edildi. Hastaların anneleri tedavi öncesi ve tedavinin 6. haftasında Çocuklar için Yaşam Kalitesi Ölçeği ve Gözden geçirilmiş Belirti Tarama Listesi-90'1 (BTL90-R) doldurdular. Çocukların yaşam kalitesi ve annelerin BTL90-R puanlarındaki değişim tekrarlayan ölçümlü ANOVA ve Wilcoxon testleri kullanılarak değerlendirildi.

Bulgular: Annelerin algıladığı toplam yaşam kalitesi tedavinin 6. haftasının sonunda başlangıca kıyasla anlamlı düzeyde artış gösterdi $(82,87 \pm 13,91$ 'e karş1 74,24 $\pm 15,40, \mathrm{p}<0,001)$ ve tüm alanlardaki artış anlamlı düzeydeydi. Ayrıca annelerin psikolojik zorlanma düzeylerini yansitan global şiddet indeksi (GŞİ) puanlarında da belirgin azalma (1,09 $\pm 0,76$ 'e karş1 $0,78 \pm 0,64$, $\mathrm{p}<0,001)$ bildirildi. Fiziksel, sosyal ve toplam yaşam kalitesi puanlarındaki fark annelerin GŞİ puanları istatistiksel olarak kontrol edildiğinde de korundu.

Sonuç: Hastalarımızda tüm yaşam kalitesi alanlarında ve toplam puanda belirgin artış gözlendi. Kabızlık belirtilerindeki azalma, fiziksel sağlık ve sosyal alandaki iyileşmeyi direkt olarak etkilerken, duygusal işlevsellikteki iyileşme, annelerin psikolojik zorlanmasının azalması ile ilişkili, dolaylı bir etki olduğu görülmektedir.

Anahtar kelimeler: Fonksiyonel kabızlık, Yaşam kalitesi, Okul öncesi çocuklar, Tedavi

Hüseyin Kılınçaslan (ه), İbrahim Aydoğdu

Çocuk Cerrahisi Anabilim Dalı, Tıp Fakültesi, Bezmialem Vakıf

Üniversitesi, Istanbul, Türkiye

e-mail: hkilincaslan@gmail.com

Osman Abalı

Çocuk Ruh Sağlı̆̆ı ve Hastalıkları Anabilim Dalı, Tıp Fakültesi, İstanbul

Üniversitesi, İstanbul, Türkiye

Mustafa Bilici

Çocuk Să̆lığı ve Hastalıkları Anabilim Dall, Tıp Fakültesi, Bezmialem Vakuf Üniversitesi, Istanbul, Türkiye

Gönderilme/Submitted: 30.09 .2013

Kabul/Accepted: 10.12 .2013

\begin{abstract}
Objective: The aim of this study was to determine whether there is a change in the quality of life (QOL) in preschool children with functional constipation (FC) after undergoing standard treatment.

Patients and Methods: Sixty-five patients, between 2-6 years of age, with FC, were included in the study. The mothers completed the Pediatric Quality of Life (QOL) Inventory and Symptom Checklist-90-Revised (SCL-90-R) before starting the treatment and at the 6 th week of the treatment. The change in QOL and SCL-90-R scores were compared using repeated measures ANOVA and Wilcoxon tests.

Results: Mother-perceived total QOL was improved at 6th week of treatment compared with baseline $(82.87 \pm 13.91$ vs 74.24 $\pm 15.40, \mathrm{p}<0.001)$ and improvement in all domains of QOL was significant. A significant decrease in the global severity index (GSI) of maternal psychological distress $(1.09 \pm 0.76$ vs $0.78 \pm$ $0.64, p<0.001)$ was also reported. Improvement in physical, social and total QOL was maintained after GSI scores of the mothers were statistically controlled.

Conclusion: Significant improvement in all QOL categories was detected. Decrease in symptoms of constipation seemed to effect physical and social aspects of QOL directly, whereas improvement in emotional functioning seemed rather be an indirect effect of treatment via decrease in psychological distress of the mothers.
\end{abstract}

Key words: Functional constipation, Quality of life, Preschool children, Treatment

\section{Giriş}

Fonksiyonel kabızlık (FK) sık görülen bir patolojidir ve bu hastalar genel pediatri polikliniklerine başvuruların \% 3'ünü, pediatrik gastroenteroloji polikliniğine başvuranların ise $\%$ 25'ini oluşturur [1]. Yakın dönemde gerçekleştirilen iki ayrı çalışmada FK'nın genel popülasyondaki çocuklarda \% 5-18 oranında görüldüğü bildirilmiştir [2,3]. Hastaların yaklaşık yarısında belirtilerin ilk bir yılda başladığı, ortalama başlangıç yaşının 2 olduğu ve en sık olarak 2 ve 4-5 yaş arasındaki çocuklarda görüldüğü bildirilmektedir $[4,5]$. FK sıklıkla tekrarlayıcı bir durumdur: beş yıllık izlemde hastaların üçte biri ile yarısında tedaviye rağmen şikayetlerin sürdüğü, dörtte birinde ise erişkinlik dönemine kadar belirtilerin devam ettiği gösterilmiştir [6]. 
Kabızlık şikayetleri ile büyümek çocuğun anne-baba ve kardeşleri ile ilişkisini, arkadaşlarıyla birlikteliklerini, okul başarısını, kendine bakım-hijyen gibi becerilerinin kazanımı gibi alanlarda bağımsızlığını etkileyerek, psikososyal gelişimini olumsuz yönde etkileyebilir [6-8]. Birçok çalışma bu çocukların daha yüksek düzeyde davranış problemi sergilediğini göstermiştir. Son on yılda, FK'nın çocuk ve ergenlerin yaşam kalitesini ne şekilde etkilediğini standart araçlarla değerlendiren çalışmalar yapılmıştır [9-14] (Tablo 1). Bu çalışmalar kabızlığı olan çocukların sağlıklılara göre duygusal, sosyal ve fiziksel olarak olumsuz biçimde etkilendiğini göstermiştir. Youssef ve ark. [9], FK'li hastaların, kendi ve anne-babalarının ifadeleriyle pek çok alanda inflamatuar barsak hastalığı olan çocuklardan daha düşük işlev gösterdiğini bildirmiştir. Çok yakın tarihli bir çalışmada da klinik başvurusu olmayan kabız çocuklarda bile; fiziksel, sosyal, duygusal ve okul işlevselliğinin olumsuz yönde etkilendiği gösterilmiştir [14].
Sağlıkla ilgili yaşam kalitesi (health-related quality of life) araçları fiziksel, sosyal ve duygusal sağlığın genel yaşam kalitesine etkisini değerlendirmede artan oranda kullanılmaktadır. Kabızlığın tedavisi ile çocuklarda davranış problemlerinin azaldığına yönelik çalışmalar bulunmakla birlikte [15-18] yaşam kalitesinin yükseldiğine dair veriler çok daha sınırlıdır. Yakın tarihli iki çalışma transkutanöz elektrik stimulasyonunun yavaş geçişli konstipasyonda [19] ve malone antegrade continence enema (MACE) prosedürünün ise inatçı tekrarlayan kabızlık veya enkopreziste [20] yaşam kalitesini artırdığını göstermiştir. Ancak bu iki yöntem de ancak seçilmiş hastalarda uygulanabilen ve FK'nın standart tedavisi olarak kabul edilemeyecek yaklaşımlardır. Literatürde FK'nin stardart tedavisinde kullanılan laksatiflerin, eğitsel ve davranışsal yöntemlerin tedavi öncesi ve sonrası dönemde yaşam kalitesine etkilerini araştıran herhangi bir çalışmaya rastlanmamıştır.

Tablo I: Kabızlığı olan çocuklarda standart araçlar kullanılarak yapılan yaşam kalitesi çalışmaları

\begin{tabular}{|c|c|c|c|c|c|}
\hline Çalışma & Popülasyon & Yaş & Araç & Bilgi kaynağ1 & Bulgular \\
\hline $\begin{array}{l}\text { Youssef ve } \\
\text { ark. [9] }\end{array}$ & $\begin{array}{l}\text { Kabızlığı olan } 80 \text {, } \\
\text { İBH'lı } 42 \text {, GÖRH'li } \\
52 \text { hasta ve } 46 \\
\text { sağlıklı kontrol }\end{array}$ & $\begin{array}{l}5-18 \\
\text { yaş }\end{array}$ & ÇIYYKÖ & $\begin{array}{l}\text { Çocuk ve } \\
\text { anne-baba }\end{array}$ & $\begin{array}{l}\text { Kabız çocuklar İBH, GÖRH ve kontrol gruplarına göre } \\
\text { toplam ve fiziksel alanlarda daha düşük yaşam kalitesi } \\
\text { göstermiştir. Kabız hastaların anne-babaları çocuklarının } \\
\text { toplam yaşam kalitesini daha düşük olarak bildirirken, } \\
\text { çocuklarının duygusal alanda kontrollerden, sosyal alanda } \\
\text { da diğer } 3 \text { grubun hepsinden daha fazla sorun yaşadığını } \\
\text { ifade etmişlerdir. }\end{array}$ \\
\hline $\begin{array}{l}\text { Faleiros ve } \\
\text { ark. [10] }\end{array}$ & $\begin{array}{l}\text { Fonksiyonel kabılı̆ı̆ } \\
\text { olan } 57 \text {, fonksiyonel } \\
\text { fekal retansiyonu olan } \\
29 \text { hasta ve } 314 \\
\text { sağlıklı kontrol }\end{array}$ & $\begin{array}{l}5-12 \\
\text { yaş }\end{array}$ & $\begin{array}{l}\text { Çocuk Sağlik } \\
\text { Ölçeği- } \\
\text { ebeveyn formu } \\
\text { (CHQ-PF50) }\end{array}$ & Anne-baba & $\begin{array}{l}\text { Defekasyon bozukluğu olan çocukların kontrollere göre } \\
\text { fiziksel ve psikososyal sağlıkla ilgili } 15 \text { alanın 14'ünde daha } \\
\text { düşük puan almışlardır. }\end{array}$ \\
\hline $\begin{array}{l}\text { Clarke ve } \\
\text { ark. [11] }\end{array}$ & $\begin{array}{l}\text { Yavaş geçişli } \\
\text { kabızlığ olan } 51 \\
\text { hasta, } 79 \text { sağlıklı } \\
\text { kontrol }\end{array}$ & $\begin{array}{l}8-18 \\
\text { yaş }\end{array}$ & ÇIYYKÖ & $\begin{array}{l}\text { Çocuk ve } \\
\text { anne-baba }\end{array}$ & $\begin{array}{l}\text { Yavaş geçişli kabızlığı olan çocuklar ve anne- babaları } \\
\text { toplam yaşam kalitelerini daha düşük olarak bildirmişlerdir. } \\
\text { Hasta çocukların anne-babaları çocuklarından daha düşük } \\
\text { yaşam kalitesi bildirirken, kontrollerde böyle bir durum } \\
\text { gözlenmemiştir. }\end{array}$ \\
\hline $\begin{array}{l}\text { Bongers ve } \\
\text { ark. [12] }\end{array}$ & $\begin{array}{l}\text { Kabılik ve fekal } \\
\text { inkontinansı olan } 114 \\
\text { hasta }\end{array}$ & $\begin{array}{l}8-18 \\
\text { yaş }\end{array}$ & $\begin{array}{l}\text { Defekasyon } \\
\text { bozukluğu } \\
\text { listesi (DDL) }\end{array}$ & Çocuk & $\begin{array}{l}\text { Fekal inkontinansın daha sık olması duygusal ve sosyal } \\
\text { alanlarda yaşam kalitesinde azalma ile ilişkili bulundu. }\end{array}$ \\
\hline $\begin{array}{l}\text { Oostenbrink } \\
\text { ve ark. [13] }\end{array}$ & $\begin{array}{l}\text { Fonksiyonel karın } \\
\text { şikayetleri olan } 81 \\
\text { hasta (fonksiyonel } \\
\text { konstipasyonu olan } \\
63 \text {, diğer (örn: IBSS, } \\
\text { FKA) } 18 \text { hasta) }\end{array}$ & $\begin{array}{l}5-72 \\
\text { ay }\end{array}$ & $\begin{array}{l}\text { Bebek ve okul } \\
\text { öncesi çocuklar } \\
\text { için yaşam } \\
\text { kalitesi ölçeği } \\
\text { (I/T QOLQ) }\end{array}$ & Ebeveyn & $\begin{array}{l}\text { Referans değerlerle karşılaştırıldığında fonksiyonel karın } \\
\text { yakınmaları olan hastalar yaşamın pek çok alanında (fiziksel } \\
\text { işlev, genel gelişim, vücut ağrısı, mizaç ve duygudurum, } \\
\text { genel sağlık algısı ve ebeveynin duygusal etkilenmesi) } \\
\text { olumsuzluk yaşamaktadır. Fonksiyonel kabızlığı olan } \\
\text { hastalarda değerler diğer hastalara göre daha düşük. }\end{array}$ \\
\hline $\begin{array}{l}\text { Rajindrajith } \\
\text { ve ark. [14] }\end{array}$ & $\begin{array}{l}\text { Okula giden } 1792 \\
\text { ergen }\end{array}$ & $\begin{array}{l}13-18 \\
\text { yaş }\end{array}$ & $\begin{array}{l}\text { ÇİYKÖ-ergen } \\
\text { formu }\end{array}$ & Çocuk & $\begin{array}{l}\text { Roma III ölçütlerine göre konstipasyon tanısı alan ergenler } \\
(\% 7,7) \text { fiziksel, sosyal, duygusal ve okul işlevselliği } \\
\text { bakımından diğerlerinden daha düşük puanlar aldı. }\end{array}$ \\
\hline
\end{tabular}


Biz bu çalışmada FK'li okul öncesi dönem çocuklarının yaşam kalitelerinin ne düzeyde olduğunu ve standart tedavinin yaşam kalitesini nasıl etkilediğini araştırdık. Özellikle bu dönem çocuklarda kabızlık, çocuğa bakan kişinin psikiyatrik durumu ile de yakından ilişkili olduğu [21] ve çocukların yaşı gereği yaşam kalitesi değerlendirmesinde sadece annelerden bilgi alındığı için annelerin tedavi öncesi ve sonrası psikiyatrik özellikleri de incelendi.

\section{Hastalar ve Yöntem}

Çalışma için gerekli onay Bezmialem Vakıf Üniversitesi etik kurulundan alındı. Mart 2012- Ağustos 2012 tarihleri arasında Bezmialem Vakıf Üniversitesi Tıp Fakültesi Çocuk Cerrahisi polikliniğine başvuran ve FK tanısı konularak tedaviye alınan çocukların annelerine çalışmanın amacı ve protokolü ile ilgili bilgi verildi. Çalışmaya dahil edilme şartları çocuğun 2-6 yaş arasında olması, FK tanısı alması, annesi ile birlikte yaşaması, tedavinin anne ile birlikte ve en az 6 hafta boyunca sürdürülmesi, annenin çalışmaya katılmayı ve gerekli ölçekleri doldurmayı kabul etmesi idi. FK tanısı için en az 2 ay boyunca şu 6 belirtiden en az ikisinin karşılanması gerekiyordu: Defekasyon sıklığı <3/ hafta, fekal inkontinans $>1 /$ hafta, tuvaleti t1kayabilecek büyüklükte fekal kitle geçişi, fekal kitlenin karın palpasyonunda veya rektal tuşe ile palpe edilebilmesi, kakasını tutma ve ağrılı kaka yapma [22]. Her hastadan detaylı tıbbi öykü alındı. Burada mekonyum çıkışının zamanı sorgulandı. Rektal incelemeyi de içeren detaylı fizik muayene yapıldı. Şu durumlara sahip çocuklar çalışma dışı bırakıldı: Hirschsprung hastalığı, anorektal malformasyon, spina bifida okülta, hipotiroidi başta olmak üzere kabızlık nedeni olabilecek hormonal durumlar, diğer metabolik ve gelişimsel geriliğe bağlı defekasyon bozuklukları ve laksatif dışında ilaç kullanımı.

Çalışmaya katılan çocukların anneleri sosyodemografik özellikler, çocuğun psikomotor gelişimi ve kabızlığın klinik özelliklerini içeren bir formu araştırmacıların yardımıyla doldurdular. Ayrıca tedavi öncesi Çocuklar için Yaşam Kalitesi Ölçeğini (ÇİYKÖ) ve Gözden geçirilmiş Belirti Tarama Listesi-90'ni (BTL-90-R) doldurarak standart tedaviye alındılar. Tedavi protokolü şunlardan oluşuyordu: Aileye, normal bağırsak hareketleri, kabızlığın sebepleri, çocuklardaki sıklığı gibi bilgilerin verilmesi, tuvalet eğitiminin gözden geçirilmesi ve kazandırılması (beslenme sonrası uygun pozisyon ve sürede tuvalette oturulması gibi), diyetin düzenlenmesi (sıvı ve lif alımını artırılması, aşırı inek sütü alımının kısıtlanması gibi), rektumun lavmanla veya oral laksatiflerle boşaltılması; uygun laksatif tedavisi ile çocuğun uygun kıvamda ve günlük dışkılamasının sağlanması. Tedavinin 6. haftasının sonunda çocukların FK ile ilişkili semptomları tekrar değerlendirildi, ÇIYKÖ ve BTL-90-R tekrar dolduruldu.

\section{Çocuklar için Yaşam Kalitesi Ölçeği}

Varni ve ark. [23] tarafından 2-18 yaşlar arasındaki çocuk ve ergenelerde yaşam kalitesini ölçmek için geliştirilmiş bir öz bildirim ölçeğidir. 2-4 yaşlar arasında sadece ebeveynlerin doldurduğu form, sonraki dönem için hem çocuk hem de ebeveyn formları vardır. Çalışmamızda Üneri'nin 2-7 yaşlar arası çocuklarda geçerlik ve güvenilirlik çalışmasını yaptığı form kullanılmıştır [24]. Fiziksel (8 madde), duygusal (5 madde), sosyal (5 madde), okul (5 madde) işlevselliğini değerlendiren 23 maddeden oluşan beşli-likert tipi bir ölçektir. Duygusal, sosyal ve okul alanlarındaki puandan psikososyal işlevsellik puanı ve hepsinden toplam yaşam kalitesi puanı hesaplanır. Maddeler 0 ile 100 arasında puan almaktadır; hiçbir zaman 100, nadiren 75 , bazen 50 , siklikla 25 ve hemen her zaman 0 puan olarak kaydedilir. Maddelerden alınan puanlar toplanıp doldurulmuş olan madde sayısına bölünerek ölçeğin toplam puanı elde edilir. Ölçekten alınan toplam puanın yüksekliği yaşam kalitesinin yüksekliğini gösterir.

\section{Belirti Tarama Listesi}

Derogatis ve ark. tarafindan geliştirilen, 90 maddeden oluşan, erişkinlerde psikolojik belirti ve zorlanma düzeyini değerlendiren bir öz bildirim ölçeğidir [25]. Yaygın biçimde kullanılan ölçeğin Türkçe geçerlilik ve güvenirlilik çalışması yapılmıştır [26]. Her madde 0 (yok) ile 4 arasında (aşırı derecede) beşli-likert biçiminde değerlendirilir ve 9 klinik değer ortaya çıkar: somatizasyon, obsesif-kompulsif, kişiler arası duyarlılık, depresyon, anksiyete, öfkedüşmanlık, fobik anksiyete, paranoid düşünce and psikotizm. Tüm maddelerin ortalamasını ifade eden global şiddet indeksinin (GŞI) güncel psikolojik zorlanma (distress) düzeyini en iyi gösteren ölçüt olduğu bildirilmiştir.

\section{İstatistiksel Analiz}

Tanımlayıcı istatistikler sürekli değerler için ortalama \pm ss, kategorik değerler içeren değişkenler için ise sıklık (\%) verilmiştir. Tedavi öncesi ve sonrası değişimlerin analizinde Kolmogorov Smirnov testine göre normal dağılan parametreler için tekrarlı ölçümlü varyans analizi (Bonferroni düzeltmeli), normal dağılmayan parametreler için Wilcoxon testi kullanıldı. Tedavi öncesi ve sonrası farkın göreceli büyüklüğünü ifade etmesi açısından etki-düzeyleri (ED) partial eta squared ( $\eta 2$ ) ya da korelasyon katsayısı (r; Wilcoxon testinde hesaplanan $\mathrm{Z}$ değeri/ $\sqrt{\mathrm{N}}$ ) olarak hesapland1. Cohen [27] $\eta 2=0,01$ veya $r=0,1$ 'ın düşük etki düzeyi, $\eta 2=0,06$ veya $r=0,3$ 'ün orta etki büyüklükleri ve $\eta 2=0,14$ veya $\mathrm{r}=0,5$ ' in yüksek etki büyüklüklerine karşılık geldiğini bildirmiştir. İstatistiksel analiz SPSS v.15 ile gerçekleştirildi ve anlamlılık düzeyi sınırı olarak $\mathrm{p}<0,05$ kabul edildi. 


\section{Bulgular}

Yaş ortalaması 43,6 $\pm 15,4$ ay olan 37'si (57\%) kı olmak üzere 65 çocuk çalışmaya alındı. Annelerin ortalama yaşı 30,95 4 ,98 olup, 56's1 (\%87) ev hanımıdı. Annelerin 47'si (72\%) ilköğretim, 15’i (\%23) lise ve 3'ü (\%5) üniversite mezunuydu. Gelir düzeylerini annelerin 3'ü (5\%) düşük, 41 'i (63\%) orta ve 21 'i (32\%) iyi düzeyde olarak bildirdi. Çocukların 7'si (\%11)'i okul öncesi eğitime devam ediyordu.

Kabızlık yakınmalarının ortalama $26,5 \pm 16,9$ ayda (3 hafta- 69 ay) başladı $\breve{g}$, hastaların yaklaşık dörtte birinde ilk 1 yaşta, yarısında ilk 24 ayda belirtilerin bulunduğu bildirildi. Ortalama kabızlık süresi $17,12 \pm 12,62$ ay (3-60 ay) idi. Hastaların 27'sinin (\%42) ilk tedavi başvurusu olup, $35^{\prime}$ inde (\%54) ailede kabızlık öyküsü mevcuttu.

Hastaların kabızlık tedavisi öncesi, tedavinin 3. haftası ve 6. haftası sonu itibariyle belirtilerinin seyri Tablo II'de görülmektedir. Tedavi öncesindeki belirti sayısı ile aynı dönem sosyal işlevsellik puanları arasında anlamlı negatif korelasyon görüldü $(\mathrm{r}:-0,28, \mathrm{p}=0,02)$. Tedavi öncesi dönemde ağrılı kaka yapan çocukların ağrısı olmayanlara göre sosyal sağllk $(\mathrm{p}=0,028)$, psikososyal sağlık $(0,024)$ ve toplam sağlık $(0,036)$ alanlarında daha düşük işlevsellik gösterdiği bulundu. Çocukların yaşları ile tedavi öncesi ve sonrası toplam yaşam kalitesi puanları arasında negatif korelasyon gözlendi (Spearman korelasyon, sırasıyla $\mathrm{r}=0,25, \mathrm{p}=0,048$ ve $\mathrm{r}=0,26, \mathrm{p}=0,042$ ).

Tablo II: Tedavinin başlangıcı, tedavi sonrası 3. ve 6. haftalar itibariyle hastaların kabızlık belirtilerin seyri

\begin{tabular}{lccc}
\hline & $\begin{array}{c}\text { Tedavi } \\
\text { başlangıcı } \\
\mathrm{N}(\%)\end{array}$ & $\begin{array}{c}\text { 3. haftanın } \\
\text { sonu } \\
\mathrm{N}(\%)\end{array}$ & $\begin{array}{c}\text { 6. haftanın } \\
\text { sonu } \\
\mathrm{N}(\%)\end{array}$ \\
\hline $\begin{array}{l}\text { Haftalık } \\
\text { defekasyon } \\
\text { sıklığı }<3\end{array}$ & $52(\% 80)$ & $5(\% 8)$ & $1(\% 2)$ \\
$\begin{array}{l}\text { Haftalık fekal } \\
\text { inkontinans }>1\end{array}$ & $9(\% 14)$ & $2(\% 3)$ & $0(\% 0)$ \\
$\begin{array}{l}\text { Tuvaleti } \\
\text { tıkayabilecek } \\
\text { büyüklükte fekal } \\
\text { kitle }\end{array}$ & $11(\% 17)$ & $2(\% 3)$ & $0(\% 0)$ \\
$\begin{array}{l}\text { Karın/rektumda } \\
\text { fekal kitle } \\
\text { palpasyonu }\end{array}$ & $7(\% 11)$ & $1(\% 2)$ & $1(\% 2)$ \\
$\begin{array}{l}\text { Kaka tutma } \\
\begin{array}{l}\text { Ağrılı kaka } \\
\text { yapma }\end{array}\end{array}$ & $44(\% 68)$ & $29(\% 45)$ & $4(\% 6)$ \\
$\begin{array}{l}\text { FK tanısını } \\
\text { karşılama }\end{array}$ & $32(\% 49)$ & $22(\% 34)$ & $10(\% 15)$ \\
\hline
\end{tabular}

$\mathrm{N}$ : Belirtinin görüldüğü hasta sayısı
Tedavi öncesi ve tedavinin 6 . haftasının sonunda çocukların yaşam kalitesi ve annelerin psikolojik zorlanma puanlarındaki değişiklik Tablo III'de görülmektedir. Tedavi sonrasında çocukların fiziksel, duygusal ve sosyal yaşam kalitelerinde yüksek düzeyde artış saptanmıştır. Okul öncesi eğitim alan hasta sayısının az olmasına rağmen bu dönemde okula giden çocukların okul işlevselliği alanındaki değişim de istatistiksel olarak anlamlı bulunmuştur. Annelerdeki psikolojik zorlanma ile ilgili hemen her alanda orta düzeyde bir azalma görüldü.

Annelerin psikolojik zorlanmalarının azalmasının, çocukların yaşam kalitesi düzeylerindeki artışa etkisini kontrol etmek amaciyla, annelerin tedavi öncesi ve sonrası GŞİ puanları kovaryant olarak varyans analizine dahil edildi. Bu durumda da çocukların tedavi ile fiziksel sağlık (; $\left.\eta^{2}=0,19, p<0,001\right)$, sosyal sağl1k $\left(\eta^{2}=0,126, p=0,004\right)$, psikososyal sağlık $\left(\eta^{2}=0,099, p=0,01\right)$ ve global yaşam kalitesi $\left(\eta^{2}=0,18, p=0,001\right)$ puanlarındaki artış anlamlılığını korudu. Ancak duygusal sağlık ve okul işlevselliği alanlarındaki değişim anlamlılığını kaybederken (sirasiyla $\eta^{2}=0,048, p=0,08$ ve $\eta^{2}=0,013, p=0,83$ ), annelerin tedavi sonrası GŞİ puanının duygusal işlevselliğin artışı ile ilişkili olduğu görüldü $\left(\eta^{2}=0,07, \mathrm{p}=0,034\right)$.

\section{Tartışma}

Çalışmamız okul öncesi dönemde fonksiyonel kabızlığın çocukların fiziksel sağlığının yanı sıra sosyal, duygusal ve okul işlevselliğini de olumsuz biçimde etkilediğini göstermiştir. Ayrıca bu dönemde uygulanan standart tedavinin gayet etkili olduğu bulunmuş, 6 haftalık tedavi sonrasında hastaların büyük bölümünde kabızlıkla ilgili belirtilerinin kontrol altına alındığ 1 ve her alanda yaşam kalitelerinin arttığı gözlenmiştir. Tedavi öncesi ve sonrası annelerin de psikolojik zorlanmalarının anlamlı şekilde azaldığı ve bunun da çocukların özellikle duygusal alanda yaşam kalitesini anlamlı biçimde artırdığı gösterilmiştir. Kabızlık belirtilerinin kontrolü, annelerin psikolojik sıkıntısını azaltma etkisinden bağımsız olarak çocukların fiziksel sağlık, sosyal ve psikososyal işlevselliğini ve toplam yaşam kalitesini artırmaktadır.

Okul öncesi FK'li çocukların yaşam kalitesi ile ilgili literatür incelendiğinde sadece Oostenbrink ve ark.'nın [13] çoğunluğu FK tanılı çocuklardan oluşmak üzere (\%78) 81 tane fonksiyonel gastrointestinal sistem rahatsızlığ olan çocuğu incelediği çalışma göze çarpmaktadır (Tablo I). Bizim hastalarımıza benzer biçimde yaşamın pek çok alanında akranlarından daha düşük işlevsellik sergileyen bu çocuklarda puanlar, özellikle FK grubunda daha da düşmekteydi. Gerek kullanılan ölçeğin bizim çalışmamızdan farklılı̆̆ 1 , gerekse FK'li çocukların diğerleriyle birlikte değerlendirilmesi etkilenme düzeylerini karşılaştırmamızı engellemektedir. 
Tablo III : Kabızlık tedavisi öncesi ve tedavinin 6. haftasındaki yaşam kalitesi ve annelerin psikolojik zorlanma puanlarındaki değişim

\begin{tabular}{|c|c|c|c|c|}
\hline & $\begin{array}{c}\text { Tedavi başlangıcı } \\
\text { (Ortalama } \pm \text { ss) }\end{array}$ & $\begin{array}{c}\text { 6. hafta } \\
\text { (Ortalama } \pm \text { ss) }\end{array}$ & $\mathrm{p}$ & $\begin{array}{c}\text { Etki büyüklüğü } \\
\eta^{2} / r\end{array}$ \\
\hline Fiziksel sağlık† & $73,08 \pm 17,46$ & $81,45 \pm 17,20$ & $<0,001$ & $\eta^{2}=0,20$ \\
\hline Duygusal sağlık† & $71,23 \pm 20,56$ & $80,92 \pm 16,25$ & $<0,001$ & $\eta^{2}=0,22$ \\
\hline Sosyal sağlik $\dagger$ & $80,86 \pm 19,75$ & $87,62 \pm 16,08$ & $<0,001$ & $\eta^{2}=0,19$ \\
\hline Okul işlevselliği† & $79,29 \pm 18,13$ & $86,43 \pm 19,09$ & 0,035 & $\eta^{2}=0,55$ \\
\hline Psikososyal sağlık† & $75,82 \pm 17,18$ & $84,27 \pm 13,95$ & $<0,001$ & $\eta^{2}=0,25$ \\
\hline Toplam yaşam kalitesi $\dagger$ & $74,24 \pm 15,40$ & $82,87 \pm 13,91$ & $<0,001$ & $\eta^{2}=0,27$ \\
\hline BTL-90-R GŞİ & $1,09 \pm 0,76$ & $0,78 \pm 0,64$ & $<0,001$ & $\mathrm{r}=0,44$ \\
\hline BTL-90-R somatizasyon $\leftarrow$ & $1,27 \pm 0,83$ & $0,81 \pm 0,68$ & $<0,001$ & $\mathrm{r}=0,49$ \\
\hline BTL-90-R obsesif-kompülsif & $1,14 \pm 0,83$ & $0,87 \pm 0,78$ & $<0,001$ & $\mathrm{r}=0,34$ \\
\hline BTL-90-R kişiler arası duyarlılık & $1,21 \pm 0,95$ & $0,86 \pm 0,82$ & $<0,001$ & $\mathrm{r}=0,40$ \\
\hline BTL-90-R depresyon: & $1,23 \pm 0,90$ & $0,86 \pm 0,82$ & $<0,001$ & $\mathrm{r}=0,42$ \\
\hline BTL-90-R anksiyete & $1,04 \pm 0,87$ & $0,72 \pm 0,73$ & $<0,001$ & $\mathrm{r}=0,37$ \\
\hline BTL-90-R öfke-düşmanlık & $1,18 \pm 1,04$ & $0,85 \pm 0,76$ & $<0,001$ & $\mathrm{r}=0,36$ \\
\hline BTL-90-R fobik anksiyete $\ddagger$ & $0,85 \pm 0,91$ & $0,62 \pm 0,67$ & 0,007 & $\mathrm{r}=0,24$ \\
\hline BTL-90-R paranoid düşüncet & $1,05 \pm 0,93$ & $0,81 \pm 0,83$ & $<0,001$ & $\mathrm{r}=0,31$ \\
\hline BTL-90-R psikotizm $\ddagger$ & $0,70 \pm 0,73$ & $0,59 \pm 0,91$ & $<0,001$ & $\mathrm{r}=0,31$ \\
\hline BTL-90-R diğer belirtilerł & $1,08 \pm 0,79$ & $0,76 \pm 0,73$ & $<0,001$ & $\mathrm{r}=0,37$ \\
\hline
\end{tabular}

$\dagger$ Tekrarlayan ölçümlü varyans analizi, † Wilcoxon test, ss: standart sapma, $\eta^{2}=$ parsiyel eta squared, r= korelasyon katsayısı, BTL: Belirti tarama listesi, GŞ̇: Global şiddet indeksi

Ebeveynlere ÇİYKÖ doldurtarak FK'li çocukların yaşam kalitesini değerlendiren iki çalışmaya rastlandı. Youssef ve ark.'nın [9] değerlendirdiği 5-18 yaş grubundaki hastaların puanlarını bizim hastalarımızın puanları ile karşılaştırdığımızda; fiziksel sağlık ve okul işlevselliği bakımından iki çalışmadaki olgular benzemekle birlikte (ortalamaların karşılaştırılması testi ile $\mathrm{p}>0,05$ ), duygusal, sosyal ve toplam yaşam kalitesi bakımından hastalarımızdan daha düşük işlevsellik göstermekteydi (her üçü için $\mathrm{p}<0,0001)$. Diğer çalışmada ise Clarke ve ark. [11] yavaş geçişli kabızlığı olan 8-18 yaş grubundan 51 hastayı değerlendirmiştir. $\mathrm{Bu}$ hastaların anne-baba bildirimi ile fiziksel sağlık puanları çalışmamızdaki olgulara benzemekle $(\mathrm{p}=0,37)$ birlikte, psikososyal ve toplam yaşam kalitesi puanları bizim olgularımızdan daha düşüktü (sırasıyla $\mathrm{p}<0,001$ ve $\mathrm{p}<0,01$ ). Sonuç olarak, FK'l1 çocuklar okul öncesi dönemde daha büyük çocuklara göre fiziksel sağlık bakımından benzer düzeyde zorluk yaşamalarına rağmen psikososyal alanda daha az etkilenmiş görünmektedir. Bazı çalışmalar kaka kaçırmanın eşlik ettiği hastalarda yaşam kalitesinin daha da olumsuz etkilendiğini göstermiştir [14,28]. Bizim hastalarımızda kaka kaçırma daha az bildirilmiştir. Kaka kaçıranların bir kısmının tuvalet eğitimi döneminde olması sebebiyle de bu durum fazlaca sorun oluşturmuyor olabilir. Ayrıca yaş arttıkça çocuğun tuvaletini kontrol yeteneği olgunlaşmaktadır. $\mathrm{Bu}$ durum hem çocuktan beklentiyi ve hem de çocuğun psikososyal yükünü artırıyor olabilir.
Çalışmamızdaki tedaviye yüksek yanıt oranı literatürde bildirilen \%60-90'lık remisyon oraniyla uyumludur [28]. Altı haftalık tedavi sonrası hastaların sadece biri hala kabızlık ölçütlerini karşılarken, 14 tanesinde de birer kabızlık belirtisi gözlenmeye devam etti. Rezidüel belirtilerden en sık görülen ağrılı ve zor bağırsak hareketleri (10 hasta), ikinci sıklıkta ise kakasını tutma davranışıdır (4 hasta). Genel olarak kabızlık belirtilerinde belirgin azalma ve 6 haftalık tedavi ile fiziksel sağlıkla ilgili yaşam kalitesinde yükselmeye rağmen hastaların yaklaşık dörtte birinde rezidüel belirtilerin devam etmesi kabızlık tedavisinin sürdürülmesi gerektiğini göstermektedir. Ayrıca hastaların bir kısmındaki düzelmeyi bazı dönemlerde kötüleşmelerin de takip edebilmesi sebebiyle kronik kabızlıkta tedavi süresinin 6-24 ay arası olması gerektiği önerilmektedir (28).

FK'nin tedavi edilmesi ile pek çok alanda yaşam kalitesinde yükselme olması çalışmamızın en önemli bulgusudur ve bildiğimiz kadarıyla çocuklarda bu bulguya literatürde daha önce rastlanmamıştır. Wald ve ark.'nın 2011'de yayımladıkları gözden geçirmelerinde [29], kabızlığın başarılı bir şekilde tedavisinin erişkinlerde yaşam kalitesini artırdığını, ancak çocuklarda bu konuyla ilgili herhangi bir çalışmaya rastlanmadığını bildirmişlerdir. Çocuklarda tedavi modaliteleri arasında sadece yavaş geçişli konstipasyonda transkutanöz elektrik stimulasyonun ve standart tedavilere yanıt vermeyen çok dirençli hastalarda MACE protokolünün yaşam kalitesini artırdığına yönelik 
çalışmalar vardır. Ancak bu yöntemlerin çocuklarda uygulanabilirliği sınırlıdır. Diğer hastalıklarda olduğu gibi FK'u olan çocukların tedavisinde de yaşam kalitesi parametrelerinin de değerlendirilmesi giderek daha fazla önem kazanmaktadır.

Çalışmamızda kabızlık tedavisi sonrasında çocukların fiziksel, duygusal ve sosyal yaşam kalitelerinde yüksek düzeyde artış ile beraber annelerinde psikolojik sıkıntılarında azalma olduğu görülmüştür. Annelerin psikolojik rahatlamalarının etkisi ekarte edildiğinde bile çocukların fiziksel sağlık, sosyal işlevsellik ve toplam yaşam kalitesinin artmış olması tedavinin direkt etkisi olarak kabul edilebilir. Duygusal uyumda ise özellikle okul öncesi dönemde anne ile ilişki temel bir öneme sahip olduğu için bu alandaki düzelme anne-çocuk ilişkisinin düzelmesi ile ilgili dolaylı bir etki gibi görünmektedir.

Kabızlık tedavisi ne kadar erken dönemde olursa yanıtta o kadar iyi olmaktadır [30]. Bu çalıșmada, tuvalet eğitiminin gözden geçirilmesi ve kazandırılması, diyetin düzenlenmesi ve laksatif tedavisi ile çocuğun uygun kıvamda günlük dışkılamasının sağlanması protokolünden oluşan kısa dönemli standart kabızlık tedavisinin hem çocukların yaşam kalitelerinin yükseltilmesinde hem de annelerinin psikolojik zorlanmasının azaltılmasında etkili olduğu gösterilmiştir. FK tedavisiyle ortaya konulan fiziksel ve duygusal iyileşmenin ne oranda sürdügünün belirlenebilmesi için daha uzun süre takipli çalışmalara ihtiyaç vardır.

\section{Kaynaklar}

1. Van Dijk M, Benninga MA, Grootenhuis MA, Last BF. Prevalence and associated clinical characteristics of behavior problems in constipated children. Pediatrics 2010;125:e309-17. doi: 10.1542/ peds.2008-3055

2. Saps M, Sztainberg C, Di Lorenzo C. A prospective communitybased study of gastroenterological symptoms in school-age children. J Pediatr Gastroenterol Nutr 2006;43:477-82. doi: 10.1097/01. mpg.0000235979.41947.f6

3. Wald E, Di Lorenzo C, Cipriani L, Colborn DK, Burgers R, Wald A. Bowel habits and toilet training in a diverse population of children. $\mathrm{J}$ Pediatr Gastroenterol Nutr 2009;48:294-8. doi: 10.1097/ MPG.0b013e31817efbf7

4. Miele E, Simeone D, Marino A, et al. Functional gastrointestinal disorders in children: An Italian prospective survey. Pediatrics 2004;114:73-8. doi: 10.1254/jphs.FPE04003X

5. Van den Berg MM, Benninga MA, DiLorenzo C. Epidemiology of childhood constipation: A systematic review. Am J Gastroenterol 2006;101:2401-9. doi: 10.1111/j.1572-0241.2006.00771.x

6. Bongers ME, Benninga MA. Long-term follow-up and course of life in children with constipation. J Pediatr Gastroenterol Nutr 2011;53 Supp12:S55-6.

7. Lisboa VC, Felizola MC, Martins LA, Tahan S, Neto UF, de Morais MB. Aggressiveness and hostility in the family environment and chronic constipation in children. Dig Dis Sci 2008;53:2458-63. doi: 10.1007/s10620-008-0230-1

8. Kaugars AS, Silverman A, Kinservik M, et al. Families' perspectives on the effect of constipation and fecal incontinence on quality of life. J Pediatr Gastroenterol Nutr 2010;51:747-52 . doi: 10.1097/ MPG.0b013e3181de0651

9. Youssef NN, Langseder AL, Verga BJ, Mones RL, Rosh JR. Chronic childhood constipation is associated with impaired quality of life: a case-controlled study. J Pediatr Gastroenterol Nutr 2005;41:56-60. doi: 10.1097/01.mpg.0000167500.34236.6a

10. Faleiros FT, Machado NC. Assessment of health-related quality of life in children with functional defecation disorders. J Pediatr (Rio J) 2006;82:421-5. doi:10.2223/JPED. 1530

11. Clarke MCC, Chow CS, Chase JW, Gibb S, Hutsun JM, Southwell BR. Quality of life in children with slow transit constipation. J Pediatr Surg 2008;43:320-4. doi: 10.1016/j.jpedsurg.2007.10.020

12. Bongers ME, Van Dijk M, Benninga MA, Grootenhuis MA. Health related quality of life in children with constipation-associated fecal incontinence. J Pediatr 2009;154:749-53. doi: 10.1016/j. jpeds.2008.11.029

13. Oostenbrink R, Jongman H, Landgraf JM, Raat H, Moll HA. Functional abdominal complaints in pre-school children: parental reports of health-related quality of life. Qual Life Res 2010;19:363-9. doi: 10.1007/s11136-009-9583-y.

14. Rajindrajith S, Devanarayana NM, Weerasooriya L, Hathagoda W, Benninga MA. Quality of life and somatic symptoms in children with constipation: a school-based study. J Pediatr 2013;163:1069-72. doi:10.1016/j.jpeds.2013.05.012

15. Nolan T, Debelle G, Oberklaid F, Coffey C. Randomised trial of laxatives in treatment of childhood encopresis. Lancet 1991;338:5237. doi: 10.1016/0140-6736(91)91097-E

16. Young MH, Brennen LC, Baker RD, Baker SS. Functional encopresis: symptom reduction and behavioral improvement. J Dev Behav Pediatr 1995;16:226-32.

17. Van der Plas RN, Benninga MA, Redekop WK, Taminiau JA, Buller HA. Randomised trial of biofeedback training for encopresis. Arch Dis Child 1996;75:367-74.

18. Levine MD, Mazonson P, Bakow H. Behavioral symptom substitution in children cured of encopresis. Am J Dis Child 1980;134:663-7.

19. Clarke MCC, Chase JW, Gibb S, Hutson JM, Southwell BR. Improvement of quality of life in children with slow transit constipation after treatment with transcutaneous electrical stimulation. J Pediatr Surg 2009;44:1268-72. doi: 10.1016/j.jpedsurg.2009.02.031

20. Har IF, Rescorla FJ, Croffie JM. Quality of life in pediatric patients with unremitting constipation pre and post Malone Antegrade Continence Enema (MACE) procedure. J Pediatr Surg 2013;48:17337. doi: 10.1016/j.jpedsurg.2013.01.045

21. Joinson C, Heron J, von Gontard A, Butler U, Golding J, Emond A. Early childhood risk factors associated with daytime wetting and soiling in school-age children. J Pediatr Psychol 2008;33:739-50. doi: 10.1093/jpepsy/jsn008

22. Benninga M, Candy DC, Catto-Smith AG, et al. The Paris Consensus on Childhood Constipation Terminology (PACCT) Group. J Pediatr Gastroenterol Nutr 2005;40:273-5. doi: 10.1097/01.MPG.0000158071. 24327.88

23. Varni JW, Seid M, Rode CA. The PedQL: measurement model for the Pediatric Quality of Life Inventory. Medical Care 1999;37:126-39. doi: 10.1097/00005650-199902000-00003

24. Üneri ÖŞ. Çocuklar için Yaşam Kalitesi Ölçeğinin 2-7 yaşlarındaki Türk çocuklarında geçerlik ve güvenirliği. Yayınlanmamış uzmanlık tezi. Kocaeli Üniv.Tıp Fak. Çocuk Psikiyatrisi AD, Kocaeli, 2005.

25. Derogatis LR. SCL-90-R: Administration, scoring and procedure Manual-I for the revised version. Baltimore: MD John Hopkins University School of Medicine, Clinical Psychometrics Unit, 1977.

26. Dag I. Reliability and validity of Symptom Check List-90-Revised among university students. Türk Psikiyatri Derg 1991;2:5-12.

27. Cohen J. Statistical power analysis for the behavioral sciences. 2nd edition. Hillsdale, New Jersey: Lawrence Erlbaum Associates, 1988.

28. Benninga MA, Voskuijl WP, Taminiau JAJM. Childhood constipation: Is there New light in the tunnel? J Pediatr Gastroenterol Nutr 2004;39:448-64. doi: 10.1097/00005176-200411000-00002

29. Wald A, Sigurdsson L. Quality of life in children and adults with constipation. Best Pract Res Clin Gastroenterol 2011; 25:19-27. doi: 10.1016/j.bpg.2010.12.004

30. Gallagher B, West D, Puntis JWL, Stringer MD. Characteristics of children under 5 referred to hospital with constipation: A one year prospective study. Int J Clin Pract 1998;52:165-7. 